\title{
Pembelajaran Sejarah Terintegrasi PPK, Literasi, Keterampilan Abad XXI (4c), dan HOTS
}

\author{
B. Fitri Rahmawati ${ }^{*}$, Muhammad Shulhan $\mathrm{Hadi}^{2}, \mathrm{Zidni}^{3}$ \\ ${ }^{1}$ Universitas Hamzanwadi; fitri.fkiphamzanwadi@gmail.com \\ ${ }^{2}$ Universitas Hamzanwadi; muhammadshulhan.hadi@hamzanwadi.ac.id \\ ${ }^{2}$ Universitas Hamzanwadi; zidnizidni92@gmail.com
}

*Korespondensi

Dikirim: 20-11-2021; Diterima: 20-12-2021; Diterbitkan: 30-12-2021

\begin{abstract}
The change in the learning paradigm that integrates Strengthening Character Education (PPK), Literacy, 4c, and HOTS is a real challenge for history learning. Therefore, it is necessary to know how the teacher's perception of it is. The aim is to explore in-depth what teachers think about it. The research method that will be used is a qualitative method with a phenomenological approach. The technique of determining the informants used the purposive sampling technique (samples aimed). The data collection technique used is in-depth interviews. The informants of this study were history teachers at SMA Negeri Lombok Timur, totaling 20 people. The data analysis technique used is the technique stated by Moustakas, namely the textural and structural description technique. The results of this study indicate that all teachers positively welcome the implementation of this integrated learning even though many obstacles are still being faced. According to them, this model is ideal so that the implementation is still in the stage of trying to achieve it. For history teachers, this integrated learning is a way to change the image of history learning which has seemed boring, only contains memorization and stories. With the emphasis on character, literacy, 4c, and HOTS both in planning, implementation, and assessment, the old-style learning process can be improved. Strengthening education has long been implemented even before the implementation of this integrated learning. As for literacy, there are still many obstacles faced because students' interest in literacy is still low. 4c and HOTS skills are still in the process of being achieved and efforts are being made by teachers.
\end{abstract}

Keywords: history learning; integrated; PPK; literacy; 4c; HOTS

Abstrak: Perubahan paradigma pembelajaran yang mengintegrasikan Penguatan Pendidikan Karakter (PPK), Literasi, 4c dan HOTS menjadi tantangan nyata bagi pembelajaran sejarah. Oleh karena itu perlu mengetahui bagaimana persepsi guru tentang itu. Tujuannya adalah untuk mengeksplorasi secara mendalam apa yang dipikirkan guru terkait hal tersebut. Adapun metode penelitian yang akan digunakan adalah metode kualitatif dengan pendekatan fenomenologi. Teknik penentuan informan menggunakan teknik purposive sampling (sampel bertujuan). Teknik pengumpulan data yang digunakan adalah wawancara mendalam (indept interview). Informan penelitian ini adalah guru sejarah di SMA Negeri Lombok Timur yang berjumlah 20 orang. Teknik analisis data yang digunakan adalah teknik yang dinyatakan Moustakas yakni teknik deskripsi tekstural dan struktural. Hasil penelitian ini menunjukkan bahwa semua guru menyambut positif pemberlakuan pembelajaran terintegrasi ini meskipun banyak kendala yang masih dihadapi. Menurut mereka model ini sangat ideal sehingga dalam implementasi masih dalam tahap upaya untuk mencapainya. Bagi guru sejarah, pembelajaran terintegrasi ini menjadi cara untuk mengubah citra pembelajaran sejarah yang selama ini 
terkesan membosankan, hanya berisi hapalan dan cerita-cerita. Dengan adanya penekananpenekanan terhadap karakter, literasi, 4c dan HOTS ini baik dalam perencanaan, implementasi maupun penilaian, maka proses pembelajaran gaya lama dapat diperbaiki. Penguatan pendidikan karakter sudah lama diterapkan bahkan sebelum diberlakukannya pembelajaran terintegrasi ini. Sedangkan untuk literasi, masih banyak kendala yang dihadapi karena minat litersi peserta didik masih rendah. Keterampilan 4c dan HOTS masih dalam proses pencapaian dan upaya-upaya yang terus dilakukan oleh guru.

Kata Kunci: pembelajaran sejarah, terintegrasi, PPK, literasi, 4c, HOTS

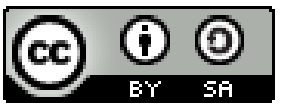

Jurnal Fajar Historia is licensed under a Creative Commons Attribution-

ShareAlike 4.0 International License.

\section{Pendahuluan}

Pembelajaran sejarah sampai saat ini masih banyak mendapatkan kritik. Beberapa faktor yang diidentifikasi sebagai penyebabnya adalah dasar filosofis tujuan pendidikan sejarah, posisi mata pelajaran sejarah dalam kurikulum, perencanaan pembelajaran, materi pembelajaran, metode pembelajaran, hasil pembelajaran sejarah yang kurang bermakna, faktor guru, peserta didik, dan masyarakat serta image membosankan yang disematkan pada mata pelajaran sejarah (Hasan, 2010; Sugiyono dan Novianti, 2018; Tok, 2016, Sayono, 2013). Berbagai upaya juga telah dilakukan untuk memperbaikinya, misalnya dengan perubahan kurikulum, pengembangan metode pembelajaran, pengembangan bahan ajar (Jantari, et al., 2019; Yusuf, et al., 2019; Sulistiawan, et al., 2019) dan pengembangan media pembelajaran (Prastowo, et al., 2019). Namun sampai saat ini pembelajaran sejarah masih dinilai jauh dari harapan. Upaya perbaikan masih perlu ditingkatkan agar kualitas pembelajaran lebih relevan, menarik dan menyenangkan bagi peserta didik.

Salah satu tantangan sekaligus sebagai sarana dan motivasi guru sejarah dalam perbaikan pembelajaran adalah dengan diberlakukannya Permendikbud No. 22 tahun 2016 yang menuntut pembelajaran yang mengintegrasikan literasi, Penguatan Pendidikan Karakter (PPK), Higher Older Thingking Skills (HOTS) dan keterampilan belajar 4C (Communication, Collaboration, Critical Thingking and Problem Solving, dan Creativity and Innovation). Penguatan Pendidikan Karakter (PPK) merupakan proses pembentukan, trasformasi, trasmisi dan mengembangkan potensi peserta didik agar berpikiran baik, berhati baik, dan berperilaku baik sesuai dengan falsafah hidup Pancasila (Kemendikbud, 2017: 21). Terdapat lima nilai utama karakter yang menjadi prioritas Gerakan Penguatan Pendidikan Karakter (Ansori, 2017). Lima nilai karakter tersebut merupakan satu kesatuan utuh yang tidak dapat dipisahpisahkan, saling mempengaruhi dan saling menentukan dan ditentukan, yakni religious, nasionalis, mandiri, gotong royong dan integritas.

Literasi merupakan kemampuan yang berkaitan dengan kegiatan membaca, berpikir, dan menulis yang bertujuan untuk meningkatkan kemampuan memahami informasi secara kritis, kreatif, dan reflektif (Suyono, et al., 2017). Lebih lanjut Suyono (2011: 44) menyatakan 
B. Fitri Rahmawati, Muhammad Shulhan Hadi, Zidni

Pembelajaran Sejarah Terintegrasi PPK, Literasi, Keterampilan Abad XXI (4c), dan HOTS

bahwa literasi sebagai basis pengembangan pembelajaran efektif dan produktif memungkinkan peserta didik terampil mencari dan mengolah informasi yang sangat dibutuhkan dalam kehidupan berbasis ilmu pengetahuan abad XXI. Oleh karena itu, literasi ini diintegrasikan dalam pembelajaran pada kurikulum 2013. Pembelajaran abad XXI adalah suatu paradigm baru pembelajaran yang diintegrasikan dalam kurikulum 2013. Pembelajaran ini diharapkan mampu membentuk kompetensi yang diperlukan di abad XXI ini yaitu yang dikenal dengan istilah 4c (communication, collaboration, critical thinking, dan creativity).

Dalam Partnership for 21st Century Learning (2015), kemampuan komunikasi mencakup pemahaman informasi yang diberikan dan kemampuan mengekspresikan ide atau konsep secara efektif. Hal senada juga dinyatakan dalam Pacific Policy Research Center (2010) bahwa keterampilan komunikasi mengacu pada kemampuan individu untuk berkomunikasi dengan jelas, menggunakan bahasa lisan atau tertulis, verbal maupun nonverbal dan berkolaborasi secara efektif (Zubaidah, 2018). Kolaborasi adalah keterampilan yang bertujuan untuk mengembangkan kecerdasan kolektif dalam hal membantu, menyarankan, menerima, dan bernegosiasi melalui interaksi dengan orang lain yang dimediasi oleh teknologi (Brown, 2015). Kolaborasi juga didefinisikan sebagai kemampuan untuk bekerja secara fleksibel, efektif, dan adil dengan orang lain untuk menyelesaikan sebuah tugas kolektif (National Education Association, 2010; Partnership for 21st Century Learning, 2015).

Johnson menjelaskan bahwa berpikir kritis adalah aktivitas mental untuk merumuskan atau memecahkan masalah, mengambil keputusan, memahami hal tertentu, menemukan jawaban untuk pertanyaan, dan menemukan jawaban yang relevan. Dengan maksud yang sama tetapi penekanan yang berbeda, Facione (2006) mendefinisikan berpikir kritis sebagai proses berpikir dalam mempertimbangkan sesuatu yang menjadi dasar pembuatan keputusan. Dalam redaksi yang berbeda Proulx (2004) mendefinisikan berpikir kritis sebagai sebuah proses menurut langkah-langkah untuk menganalisis, menguji, dan mengevaluasi argumen. Jadi berpikir kritis adalah proses berpikir tingkat tinggi dalam merumuskan masalah, mempertimbangkan dan menguji alternatif penyelesaian, sampai kepada memutuskan solusi yang tepat dalam mengatasi suatu masalah (Zubaidah, 2018).

Kreativitas adalah kemampuan untuk menghasilkan sesuatu yang baru (Zubaidah, 2018). Kreativitas merupakan hasil dari berpikir tingkat tinggi yang melampaui analisis dan evaluasi. kreativitas tercipta dari hasil berpikir kreatif. Berpikir kreatif adalah proses berpikir untuk menghasilkan ide-ide baru (Piaw, 2010). Lebih jauh lagi, Torrance (Zubaidah, 2018) mendefinisikan berpikir kreatif sebagai kemampuan untuk merumuskan masalah, membuat dugaan, menghasilkan ide-ide baru, dan mengomunikasikan hasil-hasil. Dalam redaksi yang berbeda, Hotaman (2008) memandang bahwa pemikiran kreatif sebagai kemampuan untuk membuat hubungan antara hubungan yang tidak pernah dibuat sebelumnya dan menghasilkan pemikiran dan pengalaman baru dan asli sebagai pola baru dalam skema.

Paradigma tersebut sesungguhnya bukanlah hal yang baru, sudah banyak studi empiris telah dilakukan terutama terkait dengan pengembangan kemampuan berpikir kritis (Rismaya, 
2018) maupun pengembangan pembelajaran HOTS (Pi'i, 2016). Namun, pertanyaan yang muncul dalam masalah ini adalah apakah paradigm tersebut benar-benar menginspirasi praktik pembelajaran sejarah di sekolah. Karena terkadang hasil-hasil penelitian seringkali terlalu teoritis dan tidak relevan dengan kebutuhan sekolah. Akibatnya hasil-hasil penelitian kurang menginspirasi guru-guru untuk mengimplementasikannya di sekolah. Khususnya ketika terjadi perubahan paradigma pembelajaran menjadi sangat penting untuk mengetahui apa yang guru pikirkan dan lakukan terkait hal tersebut, hal mana yang menjadi inti pokok dalam perubahan ke arah yang lebih baik. Oleh karena itu dalam penelitian ini akan dikaji mengenai persepsi guru tentang pembelajaran sejarah terintegrasi PPK, Literasi, 4c dan HOTS. Tujuannya adalah untuk mengeksplorasi secara mendalam apa yang dipikirkan guru terkait pembelajaran terintegrasi PPK, literasi, 4c dan HOTS. Penelitian ini dimaksudkan sebagai analisis kebutuhan untuk dapat berperan dalam pengembangan pembelajaran sejarah yang sesuai kebutuhan guru. Sebagaimana yang ditemukan Jeobagio (2017) bahwa perubahan kurikulum yang tidak didasarkan pada analisis kebutuhan akan berdampak pada keraguan dalam implementasinya di sekolah. Oleh karena itu, sangat penting untuk mengkaji sudut pandang guru sebagaimana yang dinyatakan Hasim et al. (2015) bahwa perubahan pendidikan tergantung pada apa yang guru 'lakukan' dan 'pikirkan'. Apa yang diyakini oleh para guru dan apa yang dilakukan para guru di kelaslah yang pada akhirnya membentuk jenis pembelajaran yang peserta didik dapatkan.

Belajar adalah aktivitas yang menghasilkan perubahan perilaku dalam diri pebelajar. Perubahan tersebut mencakup pengetahuan, sikap dan keterampilan, sebagaimana yang dinyatakan Sequeira (2012: 1) bahwa "Learning is about a change: the change brought about by developing a new skill, understanding a scientific law, changing an attitude. Sementara pembelajaran dinyatakan Sequera (2012: 3) sebagai "a set of events, outside the learners which are designed to support internal process of learning". Pembelajaran adalah usaha untuk menyiapkan kondisi untuk terjadinya proses belajar.

Hasil belajar yang diharapkan dari kegiatan belajar dan pembelajaran adalah sejumlah kompetensi yang saat ini mengalami peningkatan dari kompetensi sebelumnya. Perkembangan zaman abad XXI ini menuntut peningkatan baik dalam hal pengetahuan, sikap maupun keterampilan, sehingga penerapan kurikulum 2013 revisi 2018 menekankan integrasi Penguatan Pendidikan Karakter (PPK), Literasi, 4c, dan Higher Order Thingkings (HOTs) dalam pembelajaran.

\section{Metode Penelitian}

Metode yang digunakan dalam penelitian ini adalah metode kualitatif dengan pendekatan fenomenologis. Alasan penggunaan metode ini adalah latar alamiah seting penelitian. Dalam penelitian, peneliti tidak melakukan manipulasi terhadap objek penelitian yakni pembelajaran sejarah. Peneliti akan mendatangi lokasi penelitian mengikuti jadwal mata pelajaran sejarah yang sudah ditetapkan. Penelitian ini akan mengkaji tentang pembelajaran sejarah sebagaimana adanya kegiatan pembelajaran itu berlangsung. Peneliti ingin melihat gambaran pembelajaran sebagaimana adanya, secara netral dengan 
mengesampingkan sudut pandang peneliti, kemudian mewawancarai guru dan peserta didik secara mendalam mengenai apa yang mereka alami dalam pembelajaran dan bagaimana persepsi mereka tentang hal tersebut. Dari informasi itulah peneliti akan mengkonstruksi esensi atau makna dari realitas pembelajaran yang terjadi. Dengan maksud itulah pendekatan fenomenologi dipilih peneliti. Teknik penentuan informan menggunakan teknik purposive sampling (sampel bertujuan). Informan penelitian ini adalah 20 orang guru sejarah yang mengajar di SMA Negeri di Lombok Timur. Teknik pengumpulan data yang digunakan adalah wawancara mendalam (indept interview), observasi dan studi dokumen.

Teknik analisis data yang digunakan adalah teknik yang dinyatakan Moustakas dalam Creswell (2013: 269) yakni; 1) Mendeskripsikan pengalaman-pengalaman guru dan peserta didik ketika mengikuti pembelajaran sejarah dengan menyingkirkan pengalaman pribadi peneliti; 2) Membuat daftar pernyataan penting tentang bagaimana guru mengalami kegiatan pembelajaran dan bagaimana peserta didik mengalami kegiatan belajar sejarah; 3) Mengelompokkan permyataan-pernyataan penting tersebut ke dalam tema tertentu; 4) Menulis tentang deskripsi tekstural yakni tentang apa yang terjadi dan deskripsi structural tentang bagaimana pengalaman tersebut terjadi; 5) Memberikan makna dan esensi dari pengalaman tersebut kemudian menyajikannya dengan menggabungkan apa dan bagaimana pengalaman informan terjadi.

\section{Hasil Penelitian dan Pembahasan}

\section{Persepsi Guru Terhadap Pembelajaran Sejarah Terintegrasi PPK, Literasi, Keterampilan Abad XXI (4c), dan Kemampuan Berpikir HOTS}

Dalam Undang-Undang No. 20 tahun 2003 dinyatakan bahwa Pendidikan adalah usaha sadar dan terencana untuk mewujudkan suasana belajar dan proses pembelajaran agar peserta didik secara aktif mengembangkan potensi dirinya untuk memiliki kekuatan spiritual keagamaan, pengendalian diri, kepribadian, kecerdasan, akhlak mulia, serta keterampilan yang diperlukan dirinya, masyarakat, bangsa dan negara. Dari pengertian tersebut, dapat dilihat bahwa pendidikan adalah upaya yang dilakukan agar peserta didik dapat mengembangkan potensi diri dalam hal spiritual, sikap, pengetahuan dan keterampilan yang dibutuhkan baik untuk dirinya, masyarakat, bangsa dan negara. Dengan demikian, ada tiga hal yang harus tercover dalam pendidikan yakni potensi peserta didik, nilai-nilai spiritual dan budaya yang sudah mengakar sejak lama serta kemampuan-kemampuan yang lebih aktual untuk eksistensi dari masa ke masa.

Pada tataran realitas, seringkali ketiga hal tersebut berbenturan satu sama lain. Potensi peserta didik dapat tumbuh pada titik yang ekstrim sehingga dapat bertentangan dengan nilainilai budaya yang sudah ada. Di sisi lain, nilai-nilai budaya dipandang sudah tidak relevan lagi dengan tuntutan kehidupan abad XXI ini. Namun ketika ilmu dan teknologi berkembang pesat tanpa batas akan banyak berhadapan dengan sisi kemanusiaan yang tentu saja akan melahirkan banyak persoalan. Maka muncul pertanyaan terhadap fungsi pendidikan "apakah sebagai pemelihara status quo kebudayaan atau sebagai agen perubahan (agent of change) yang dapat menghasilkan rekonstruksi sosial yang baru yang lebih memenuhi kebutuhan 
perbedaan karakter peserta didik yang mungkin tidak serasi dengan kebudayaan yang ada (Fernandes, 2019).

Menurut persepsi guru, pembelajaran sejarah terintegrasi PPK, Literasi, keterampilan belajar 4c dan kemampuan berpikir tingkat tinggi/Higher Order Thingking Skills (HOTS) adalah model yang tetap mengakui nilai-nilai budaya sebagai karakter bangsa Indonesia tetapi tetap dapat menyesuaikan diri dengan perkembangan zaman. Artinya, antara kebudayaan dan perkembangan zaman tidak perlu dipertentangkan melainkan dapat berjalan secara beriringan dan mendapatkan tempat masing-masing di dalam pendidikan. Maka, substansi dari proses pendidikan bukan hanya aspek pengetahuan dan keterampilan, tetapi juga karakter. Bahkan menurut pemaparan para guru, karakter adalah hal yang paling utama. Jika peserta didik sudah memiliki karakter yang baik, maka akan lebih mudah diarahkan untuk melakukan kegiatan literasi, dan pada akhirnya akan lebih mudah mencapai keterampilan $4 \mathrm{c}$ dan kemampuan berpikir tingkat tinggi/higher order thinking skills (HOTS). Seperti yang dinyatakan Zuhdi (2010) bahwa pendidikan karakter di sekolah merupakan kebutuhan vital agar generasi penerus dapat dibekali dengan kemampuan-kemampuan dasar yang tidak saja mampu menjadikan long life education sebagai salah satu karakter penting untuk hidup di era reformasi yang bersifat global tetapi juga mampu berfungsi dengan peran serta yang positif baik sebagai pribadi, sebagai anggota keluarga, sebagai warga negara, maupun sebagai warga dunia.

Pembelajaran terintegrasi ini adalah pembelajaran abad XXI yang merupakan penyempurnaan K13. Model ini mengharapkan pembelajaran yang menekankan pada bagaimana peserta didik bisa berkontribusi besar dalam pembelajaran, menjadi lebih aktif, sehingga tidak terpusat pada guru. Model ini dalam pembelajaran sejarah adalah model yang sangat ideal, tetapi tetap harus dilakukan. Bagi guru sejarah sendiri, pembelajaran terintegrasi ini menjadi cara untuk mengubah citra pembelajaran sejarah yang selama ini terkesan membosankan, hanya berisi hapalan dan cerita-cerita. Dengan adanya penekanan-penekanan terhadap karakter, literasi, 4c dan HOTS ini baik dalam perencanaan, implementasi maupun penilaian, maka proses pembelajaran gaya lama dapat diperbaiki. Oleh karena itu, semua guru menyambut positif pemberlakuan pembelajaran terintegrasi ini meskipun banyak kendala yang masih di hadapi.

Pembelajaran terintegrasi PPK, literasi, 4c dan HOTS ini tidak dinyatakan secara eksplisit dalam kurikulum. Hal ini menyebabkan variasi pemahaman dari guru. Beberapa guru sudah memahami konsep pembelajaran ini dan juga sudah banyak mengikuti pelatihanpelatihan, sebagian lainnya masih merasa asing karena kurangnya pelatihan yang diikuti, bahkan ada guru yang belum pernah mengikuti pelatihan-pelatihan terkait pembelajaran terintegrasi ini. Meski demikian, semua guru mengetahui tentang perubahan pada kurikulum K13 tetapi tidak terlalu menyadari tentang pengintegrasian keempat hal tersebut dalam pembelajaran. Guru hanya mengikuti tuntutan perubahan kurikulum dalam bentuk perubahan bentuk RPP yang dibuat, penerapan beberapa model pembelajaran yang disarankan oleh kurikulum dan penyusunan soal-soal yang berorientasi HOTS. 
Menurut sebagian besar guru, integrasi PPK dan literasi dalam pembelajaran bukanlah hal yang baru. Kedua hal ini sudah terimplementasi sejak lama namun jarang disadari. Misalnya kegiatan berdoa dan mengucapkan salam adalah rutinitas yang selalu dilakukan setiap hari dalam pembelajaran, sehingga meskipun belum ditekankan untuk pendidikan karakter ini, semua aktivitas pembelajaran sudah dimulai dengan berdoa dan mengucapkan salam. Selain itu, sikap hormat terhadap guru menjadi salah satu hal yang sangat ditekankan kepada peserta didik, bahkan sering dikaitkan dengan kebarokahan ilmu yang didapatkan. Setiap bertemu dengan guru, peserta didik selalu mengucapkan salam dan mencium tangan guru ketika berjabat tangan, hal ini adalah wujud dari rasa hormat kepada guru.

Dari keempat hal ini, yang benar-benar baru bagi guru adalah 4c dan HOTS. Bahkan untuk pembelajaran HOTS sendiri masih terdapat perbedaan pemahaman apakah HOTS ini harus diintegrasikan di dalam pembelajaran ataukah hanya tertuang di dalam penilaian. Beberapa guru, terutama yang sudah banyak mengikuti diklat sudah memahami bahwa selain penilaian, terlebih dahulu peserta didik perlu dibelajarkan dengan pembelajaran yang berorientasi HOTS. Tetapi bagi sebagian lainnya, ketika membahas tentang HOTS maka yang muncul di dalam benak para guru adalah soal-soal dalam penilaian yang harus HOTS. Rasionalnya, jika peserta didik dinilai dengan soal-soal HOTS, seharusnya memang sudah mengikuti pembelajaran yang berorientasi HOTS. Jika melihat RPP yang disusun oleh guru, pada indikator dan tujuan pembelajaran sebenarnya sudah memuat HOTS, sehingga yang paling nampak HOTS nya adalah pada perencanaan dan penilaian, sedangkan pada tahap implementasi masih perlu dikaji lebih lanjut.

\section{Strategi Pencapaian Pembelajaran Terintegrasi PPK, Literasi, Keterampilan Abad XXI (4c), dan Kemapuan Berpikir HOTS}

Pembelajaran terintegrasi PPK, literasi, 4c dan HOTS adalah model pembelajaran yang mengintegrasikan keempat hal tersebut secara bersamaan dan tidak terpisahkan satu sama lain. Artinya dalam setiap pembelajaran, keempat hal ini akan selalu muncul dalam setiap langkah pembelajaran. Adapun penejelasan berikut ini hanya bertujuan untuk menjelaskan secara rinci tentang keempat hal tersebut mengenai bagaimana persepsi guru tentang masingmasing dan pada langkah pembelajaran manakah keempat hal ini dapat distimulus.

\section{Penguatan Pendidikan Karakter (PPK)}

Penguatan pendidikan karakter, selain diterapkan dalam pembelajaran di kelas, juga dilakukan di lingkungan sekolah secara umum. Kegiatan-kegiatan tersebut diantaranya adalah kegiatan imtaq yang rutin dilakukan pada hari Jum'at Kegiatan-kegiatan imtaq ini berisi kegiatan-kegiatan keagamaan seperti shalat dhuha, membaca surat Yaasiin, kultum dan juga membaca al-quran setiap pagi sebelum pembelajaran. Bahkan, sekarang ini sedang dicanangkan kegiatan Sabtu Budaya oleh Dinas Pendidikan dan Kebudayaan Nusa Tenggara Barat yang di dalamnya dapat diisi dengan kegiatan-kegiatan yang dapat memperkuat karakter peserta didik baik itu kegiatan keagamaan maupun kegiatan yang berhubungan dengan pengenalan budaya lokal. Menurut penuturan guru, kegiatan-kegiatan yang dilakukan pada 
setiap hari Sabtu ini adalah kegiatan Senam, pengenalan budaya lokal seperti baju adat, acara bersih-bersih lingkungan, dan kegiatan keagamaan lainnya.

Terdapat lima nilai karakter utama yang bersumber dari Pancasila, kebutuhan karakter nasional dan kearifan lokal yang menjadi prioritas pengembangan gerakan PPK, yaitu religius, nasionalisme, integritas, kemandirian dan kegotongroyongan (Kemendikbud, 2017: 7). Berdasarkan wawancara terhadap guru sejarah, bahwa dalam kegiatan pembelajaran di kelas, khususnya pembelajaran sejarah, penanaman karakter dilakukan dengan beberapa metode. Untuk karakter religius sudah jelas terlihat dalam kegiatan salam dan berdoa yang dilakukan di setiap awal dan akhir kegiatan pembelajaran yakni pada kegiatan pendahuluan dan penutup. Sedangkan untuk karakter nasionalisme, dapat dilakukan dengan bersamabersama menyanyikan lagu kebangsaan Nasional yakni Indonesia Raya yang dilakukan pada saat kegiatan pendahuluan. Selain itu, untuk mata pelajaran sejarah sendiri, penanaman karakter nasionalisme juga dapat dilakukan saat membahas materi pelajaran. Banyak dari materi sejarah terutama menyangkut tokoh-tokoh sejarah seperti para pahlawan, tokoh-tokoh nasional, tokoh-tokoh pemuda dan sebagainya yang dapat dijadikan sebagai contoh sikap nasionalisme. Berdasarkan hasil wawancara dan angket dari peserta didik juga diperoleh informasi bahwa salah satu hal penting dari belajar sejarah adalah para peserta didik dapat meneladani karakter yang dimiliki oleh tokoh-tokoh nasional yang mereka pelajari.

Tiga karakter berikutnya yakni integritas, kemandirian dan kegotongroyongan dapat ditumbuhkan lewat kegiatan inti pembelajaran berdasarkan pendekatan, model dan metode pembelajaran yang digunakan. Integritas atau kejujuran ini akan terlihat ketika peserta didik mengerjakan tugas-tugas yang diberikan guru. Dari tugas yang dikerjakan akan jelas terlihat apakah peserta didik dapat secara jujur mengerjakan sesuai dengan arahan yang diberikan oleh guru. Guru biasanya akan memberikan penegasan mengenai siapa saja yang tidak ikut berpartisipasi dalam pengerjaan tugas kelompok harus dilaporkan kepada guru. Integritas ini juga akan terlihat pada saat peserta didik memberikan penilaian terhadap temannya. Dari kegiatan ini dapat dilihat apakah peserta didik bisa secara jujur dan objektif di dalam memberikan penilaian.

Nilai-nilai kemandirian juga akan tertanam ketika peserta didik melakukan kegiatan literasi. Melalui kegiatan ini peserta didik dapat lebih mandiri untuk menentukan dan memenuhi tugas belajarnya. Lewat penugasan secara individu juga dapat menumbuhkan kemandirian peserta didik di dalam belajar. Sedangkan kegotongroyongan akan nampak jelas terlihat pada pembelajaran kooperatif/kolaboratif atau pembelajaran kelompok, apakah itu pada saat pengerjaan tugas maupun diskusi kelompok dan presentasi.

Pengutatan pendidikan karakter dilakukan secara kontinue, baik di lingkungan sekolah secara umum maupun secara khusus di dalam kelas oleh seluruh guru mata pelajaran. Kegitan yang berkesinambungan ini diharapkan dapat membentuk karakter peserta didik hingga menjadi sebuat habit/kebiasaan. Hal inilah yang menjadi puncak tertinggi dari penanaman sikap bahwa sikap tersebut harus benar-benar terinternalisasi ke dalam diri peserta didik hingga menjadi kepribadiannya. 
B. Fitri Rahmawati, Muhammad Shulhan Hadi, Zidni

Pembelajaran Sejarah Terintegrasi PPK, Literasi, Keterampilan Abad XXI (4c), dan HOTS

\section{Literasi}

Untuk kegiatan literasi dalam arti sempit yakni literasi sebagai kegiatan membaca dan menulis sudah dilakukan sejak lama. Bahkan ketika pembelajaran konvensional, peserta didik selalu diminta untuk mencatat materi. Kegiatan mencatat dapat dilakukan dengan mendengarkan perkataan dari guru (metode dikte) ketika guru menjadi satu-satunya sumber belajar, atau menyalin catatan dari papan tulis ketika buku sumber hanya dimiliki oleh guru, ataupun mencatat dari buku langsung ketika buku sudah dimiliki oleh peserta didik. Artinya konsep literasi yang diterapkan saat itu adalah kegiatan membaca, mendengarkan dan menulis.

Untuk saat ini, pemahaman terkait literasi sudah mulai berkembang. Literasi tidak hanya persoalan membaca dan menulis tetapi bagaimana peserta didik dapat mengumpulkan informasi dari berbagai sumber belajar dan mampu mengolah informasi tersebut. Oleh karena itu ketersediaan sumber belajar menjadi bagian yang sangat integral dalam kegiatan literasi. Sumber belajar yang dimaksud bukan hanya buku, tetapi juga dari sumber-sumber lain seperti lingkungan dan juga internet. Namun realitasnya, dalam pembelajaran sejarah di sekolah, buku adalah sumber belajar yang paling utama, ketersediaan jumlah buku menjadi syarat utama yang diajukan sebagian besar guru. Jika buku sudah tersedia secara memadai, maka salah satu faktor pendukung suksesnya pembelajaran sudah terpenuhi.

Meskipun para guru mengakui bahwa sumber belajar bukan hanya dari buku, namun untuk model pembelajaran yang lebih dominan saat ini dan bagi sekolah-sekolah yang melarang peserta didik membawa perangkat teknologi ke sekolah menjadikan buku sebagai satu-satunya sumber belajar dalam kegiatan pembelajaran di kelas. Maka untuk dapat memenuhi pembelajaran dengan beragam sumber, biasanya guru akan memberikan tugas kepada peserta didik yang dikerjakan di luar sekolah, seperti membuat makalah, laporan dan sebagainya. Pada kegiatan ini, peserta didik dapat lebih leluasa untuk menggunakan berbagai sumber belajar baik itu dari lingkungan sekitar maupun dari internet. Sedangkan bagi sekolah yang membolehkan peserta didik membawa perangkat teknologi seperti laptop dan HandPhone (HP), maka sumber belajar dalam pembelajaran bisa lebih bervariasi. Seperti yang terjadi di salah satu sekolah yang menjadi lokasi penelitian ini, setiap peserta didik memiliki laptop yang bisa dibawa pada setiap kegiatan belajar, maka kekurangan buku yang dimiliki di perpustakaan dapat disiasati. Bahkan menurut gurunya, hal ini sangat mendukung kegiatan pembelajaran. Peserta didik menjadi lebih cepat memahami karena dapat mengakses berbagai informasi dan lebih cepat menyelesaikan tugas yang diberikan.

Kedua realitas tersebut tentunya memiliki kelebihan dan kekurangannya masingmasing. Bagi sekolah yang melarang peserta didik membawa perangkat elektronik memiliki alasan bahwa daripada belajar, peserta didik lebih banyak menggunakannya untuk menonton film, main game dan perilaku-perilaku yang mengganggu lainnya. Sehingga pembatasan ini cukup beralasan untuk dapat mengurangi ketergantungan peserta didik terhadap gadget yang saat ini banyak menjadi persoalan pada anak usia sekolah. Kekurangannya adalah sumber 
belajar dari peserta didik menjadi kurang variatif, peserta didik hanya memperoleh informasi dari buku teks sehingga kemampuan literasi selain baca tulis menjadi terhambat. Bagi sekolah yang membolehkan, berarti memberikan sumber belajar yang kaya kepada peserta didik, namun diperlukan suatu sistem yang baik untuk mencegah hal-hal atau perilaku menyimpang dari peserta didik seperti perilaku-perilaku yang mengganggu kegiatan pembelajaran seperti yang disebutkan di atas.

Berdasarkan informasi yang diperoleh dari guru, strategi-strategi yang dilakukan untuk menstimulus kemampuan literasi peserta didik adalah dengan menugaskan kepada peserta didik membaca selama 10-15 menit di awal pembelajaran, kemudian meminta peserta didik mencatat apa yang sudah dibaca oleh peserta didik dan mempresentasikan di depan guru apa yang sudah dibaca dan dicatat tersebut. Strategi lainnya adalah dengan mengajak peserta didik mengunjungi perpustakaan sekolah. Hal ini dimaksudkan untuk membuat pembelajaran yang lebih bergairah, tidak monoton di satu tempat, artinya memberikan variasi dalam hal tempat sehingga peserta didik tidak merasa bosan. Menjadikan pembelajaran sejarah itu menyenangkan adalah tanggung jawab guru sejarah sampai saat ini. Sebelumnya, peserta didik selalu menganggap pembelajaran sejarah adalah pembelajaran yang membosankan, hanya berisi hapalan dan cerita-cerita belaka. Dengan variasi model pembelajaran meskipun sederhana diyakini dapat mengubah kesan peserta didik terhadap pembelajaran sejarah menjadi menyenangkan. Pada beberapa kesempatan, peserta didik tidak hanya diminta untuk membaca buku pelajaran tetapi diberikan ruang untuk memilih apa yang disukai, kemudian setelah itu diminta untuk bercerita tentang segala sesuatu yang mereka rasakan, yang mereka alami, yang mereka pahami. Hal demikian dapat membangun kedekatan antara peserta didik dan guru yang dapat menumbuhkan rasa nyaman pada diri peserta didik. Jika sudah merasa nyaman, maka kegiatan belajar akan lebih mudah dilakukan.

Memang diakui oleh semua guru bahwa minat peserta didik untuk berliterasi masih rendah. Hal ini dapat disebabkan oleh berbagai faktor yakni: pertama masih terdapat peserta didik yang belum memiliki buku sumber; kedua adalah dampak dari teknologi seperti gadget yang menyediakan banyak aplikasi hiburan seperti youtube, tiktok, facebook, twitter dan media sosial lainnya yang menurut peserta didik lebih mengasyikkan daripada kegiatan membaca buku; ketiga adalah belum adanya sebentuk reward yang diberikan oleh guru terhadap kegiatan literasi ini, sehingga nyaris tidak ada bedanya antara peserta didik yang rajin berliterasi dengan peserta didik yang tidak berliterasi. Faktor yang ke tiga ini menjadi harapan dari guru mengenai bagaimana model reward yang akan diberikan kepada peserta didik sehingga dapat menumbuhkan minat dan motivasi peserta didik; keempat adalah faktor keluarga; peserta didik yang berasal dari keluarga broken home atau keluarga dengan permasalahan-permasalahan ekonomi dan lainnya biasanya tidak memiliki minat untuk belajar khususnya juga pada kegiatan literasi ini. Faktor ini juga menjadi salah satu penyebab peserta didik tidak memiliki buku. 
B. Fitri Rahmawati, Muhammad Shulhan Hadi, Zidni

Pembelajaran Sejarah Terintegrasi PPK, Literasi, Keterampilan Abad XXI (4c), dan HOTS

\section{Keterampilan Abad XXI (4c)}

Keterampilan 4c merupakan keterampilan belajar abad XXI. Keterampilan ini penting dimiliki oleh peserta didik untuk dapat bersaing di era industri 4.0 saat ini. Kemajuan ilmu pengetahuan dan teknologi menuntut berbagai macam keterampilan yang harus dimiliki oleh peserta didik, sehingga pembelajaran saat ini tidak hanya transfer pengetahuan tetapi juga mengajarkan keterampilan.

Terhadap pembelajaran 4c ini, masing-masing guru memiliki penekanan yang berbeda. Sebagian guru menyatakan bahwa kemampuan berkomununikasi, bekerja sama dan rasa percaya diri peserta didik adalah hal yang paling utama untuk percepatan pembelajaran abad XXI ini. Namun masih banyak peserta didik yang malu, belum memiliki rasa percaya diri sehingga kerja sama, berpikir kritis, kreativitas maupun keterampilan berkomunikasi masih terkendala. Sebagian lainnya menyatakan bahwa hal yang paling penting di dalam pembelajaran adalah kolaborasi atau kerjasama dan peran dalam belajar.

Pembelajaran $4 \mathrm{c}$ adalah bagaimana peserta didik menjadi aktif, berperan dalam kegiatan belajar, mengeluarkan pendapat dan berkembangnya jiwa leadership peserta didik. Oleh karena itu, pembelajaran harus memberikan ruang kepada terbentuknya semua hal tersebut. Guru layaknya seorang sutradara yang mempersiapkan skenario dan memberikan peran-peran tertentu kepada peserta didik. Peran-peran ini dapat terlaksana ketika ada ruang, kesempatan dan kenyamanan dari peserta didik. Oleh karena itu, sebelum memulai pembelajaran, perlu dibangun chemistry antara guru dengan peserta didik, peserta didik dengan peserta didik. Untuk itu, diperlukan kesepakatan awal (MoU) antara guru dengan peserta didik mengenai model, strategi dan metode pembelajaran yang akan digunakan. Chemistry sesama peserta didik inilah yang dibangun melalui pembelajaran kolaboratif. Ketika peserta didik bekerja sama dengan sesama temannya, peserta didik menjadi lebih nyaman dalam berekspresi, berargumentasi, berdebat dan saling membimbing satu sama lain. Melalui pembelajaran kolaboratif juga kemampuan berkomunikasi peserta didik dapat didongkrak. Melalui kegiatan ini, peserta didik dapat belajar berkomunikasi sejak tahap awal berkolaborasi ketika bersamabersama mendiskusikan permasalahan yang diberikan sampai kepada tahap presentasi di depan kelas.

Integrasi 4c dalam pembelajaran dapat dilihat pada RPP dan implementasi. Pada RPP, 4c ini menjadi langkah-langkah kegiatan pembelajaran terutama pada kegiatan inti. Kegiatan 4c ini mulai dari berpikir kritis (critical thingking), kolaboratif (collaboration), komunikasi (communication) dan kreativitas (creativity). Menurut pemaparan guru, 4c ini biasanya akan muncul pada saat peserta didik berdiskusi kelompok. Kemampuan berpikir kritis peserta didik akan muncul ketika diberikan masalah, kemampuan bekerjasama/kolaborasi akan muncul ketika peserta didik bersama anggota kelompoknya berdiskusi mencari informasi sebagai jawaban dari permasalahan yang diberikan, kemampuan komunikasi juga akan terbangun pada saat diskusi kelompok serta presentasi, dan kreativitas peserta didik akan muncul ketika diminta untuk membuat karya apakah dalam bentuk catatan kesimpulan hasil diskusi maupun dalam bentuk yang lainnya seperti makalah, laporan, poster, mading dan sebagainya. 


\section{Kemampuan Berpikir Tingkat Tinggi (HOTS)}

Kesadaran guru mengenai pembelajaran sejarah terintegrasi kemampuan berpikir tingkat tinggi/higher order thinking skills (HOTS) masih perlu diperbaiki. Pasalnya, ketika berbicara tentang pembelajaran HOTS, maka yang terlintas di benak guru adalah penilaian, soal-soal yang mengandung HOTS. Namun dalam proses pembelajaran guru mengakui selalu memberikan peserta didik permasalahan yang menstimulus kemampuan analisis peserta didik. Bahkan, menurut persepsi guru, HOTS terjadi ketika anak mampu berpikir lebih tinggi, ketika peserta didik berpikir kritis yang ditunjukkan dengan kemampuan menjawab soal yang diberikan. Jika dikonversikan dengan taksonomi Bloom, maka HOTS dimulai dari c4 yaitu tahap menganalisis. Beberapa indikator HOTS yang disampaikan guru adalah 1) ketika peserta didik menyampaikan materi/informasi yang belum pernah didengar, bahkan guru pun belum pernah mendengar tentang hal tersebut; 2) ketika peserta didik menyampaikan hasil pemikiran yang lebih dari biasanya; 3) ketika peserta didik mampu menghubungkan satu peristiwa dengan peristiwa lainnya; 4) jika dikaitkan dengan jawaban pertanyaan $5 \mathrm{~W} 1 \mathrm{H}$, maka HOTS ditunjukkan dengan kemampuan peserta didik menjawab pertanyaan why (mengapa) dan how (bagaimana); 5) jika dikaitkan dengan kompetensi dasar (KD), keberhasilan pembelajaran HOTS ditandai dengan tercapainya kompetensi dasar tersebut.

Dari indicator-indikator yang disampaikan tersebut, dapat dilihat bahwa HOTS peserta didik dapat dilihat dalam proses pembelajaran. Artinya, meskipun guru memahami bahwa HOTS itu berarti penilaian, tetapi dalam tahap implementasi pembelajaran sudah tergambar pembelajaran yang berorientasi HOTS meskipun menurut guru masih sulit untuk dicapai. Oleh karena itu, guru perlu diberikan pemahaman terkait pembelajaran berorientasi HOTS sehingga dapat lebih terarah dan terukur. Pasalnya, penilaian adalah cara untuk melihat hasil dari proses pembelajaran yang dilakukan. Bagaimana mungkin hasil penilaian dapat menunjukkan ketercapaian hal tersebut jika sebelumnya peserta didik tidak diberikan pembelajaran berorientasi HOTS juga. Karena sejatinya, soal-soal yang diberikan pada saat kegiatan penilaian ditujukan untuk mengukur ketercapaian kompetensi peserta didik yang telah melalui proses pembelajaran berorientasi kompetensi yang telah ditetapkan sebelumnya. Oleh karena itu, mulai dari perencanaan yaitu ketika guru merumuskan indikator dan tujuan pembelajaran yang merupakan penjabaran dari kompetensi dasar, sudah ditentukan mengenai pengalaman belajar yang seperti apa yang akan diberikan kepada peserta didik agar tujuan tersebut dapat tercapai. Dengan demikian, kegiatan pembelajaran pun harus sesui dengan apa yang sudah direncanakan, sehingga terjadi kesesuaian antara perencanaan, implementasi dan evaluasi.

Berdasarakan penjelasan-penjelasan tersebut di atas, dapat dibangun kerangka hubungan dan posisi masing-masing dalam pembelajaran sejarah, yang dapat digambarkan sebagai berikut: 


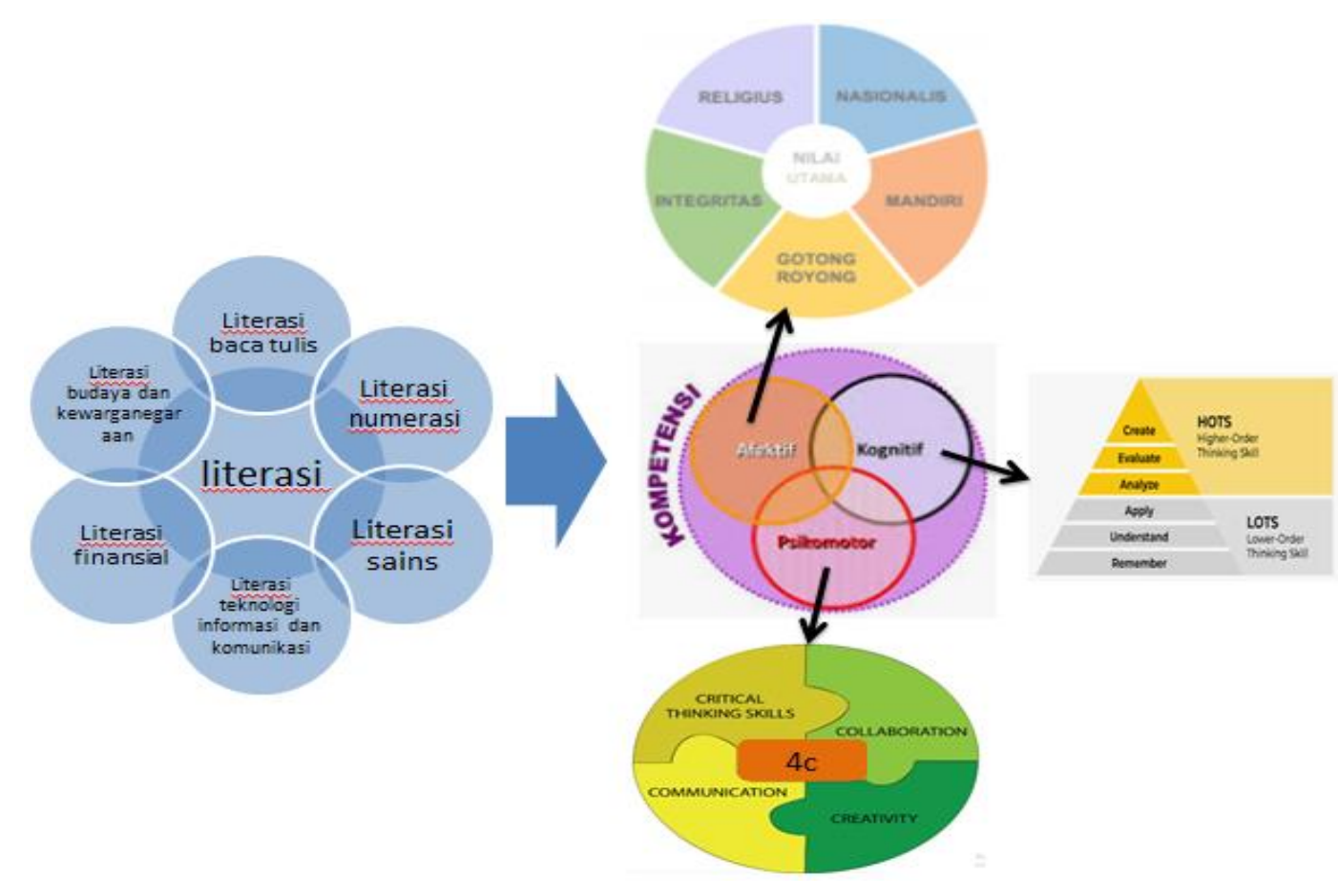

Gambar 1. Posisi dan Hubungan antara PPK, Literasi, 4c dan HOTS dalam Pembelajaran

Berdasarkan gambar tersebut diatas, dapat dijelaskan bahwa PPK, 4c dan HOTS adalah bagian dari kompetensi yang harus dicapai dalam pembelajaran, sedangkan kegiatan literasi merupakan proses pembelajaran untuk mencapai kompetensi tersebut. Menurut Somantrie (2010) bahwa kompetensi adalah gabungan kemampuan yang terdiri atas pengetahuan, sikap, dan keterampilan.

Pengetahuan adalah buah dari suatu proses berpikir (Suriasumantri, 1995). Sementara itu, Anderson membagi pengetahuan menjadi empat dimensi yaitu faktual, konseptual, prosedural dan metakognitif. Antara proses berpikir untuk mendapatkan pengetahuan dan pengetahuan sebagai hasil dari proses berpikir adalah dua hal yang menjadi isi dari aspek kognitif pada kompetensi yang harus dikuasai oleh peserta didik. Proses berpikir yang digunakan adalah taksonomi Bloom yang telah direvisi oleh Anderson yang teridiri atas $\mathrm{C} 1$ (mengingat), C2 (memahami), C3 (mengaplikasi), C4 (menganalisis), C5 (mengevaluasi) dan C6 (mencipta). C1 sampai C3 dikategorikan sebagai LOTS (lower order thinking skills/kemampuan berpikir tingkat rendah), sedangkan HOTS (higer order thinking skills/kemampuan berpikir tingkat tinggi) dimulai dari C4 sampai C6.

Ranah afektif merupakan ranah yang berkaitan dengan aspek-aspek emosional seperti perasaan, minat, sikap, dan kepatuhan terhadap moral. Didalamnya mencakup penerimaan, sambutan, tata nilai, pengorganisasian, dan karakterisasi. Dalam ranah ini peserta didik dinilai sejauh mana ia mampu menginternalisasikan nilai-nilai pembelajaran ke dalam dirinya. Ranah ini erat kaitannya dengan tata nilai dan konsep diri (Anderon, 1981) sehingga penanaman sikap dilakukan melalui pendidikan karakter. 
Ranah psikomotorik merupakan ranah yang berkaitan dengan aspek-aspek keterampilan yang melibatkan fungsi sistem saraf dan otot dan berfungsi psikis. Ranah ini terdiri dari kesiapan, peniruan, membiasakan, menyesuaikan, dan menciptakan (Haryati, 2009). Ketika peserta didik telah memahami dan menginternalisasikan nilai-nilai mata pelajaran dalam dirinya, maka tahap selanjutnya adalah bagaimana peserta didik mampu mengaplikasikan pemahamannya dalam kehidupan sehari-hari melalui perbuatan atau tindakan. Dalam konteks abad XXI terdapat keterampilan belajar yang harus dikuasai oleh peserta didik yakni, 4c (critical thinking, collaborative, communication dan creativity).

Terkait dengan hal tersebut, bahwa PPK, 4c dan HOTS merupakan isi dari kompetensi yang harus dicapai dalam pembelajaran sejarah saat ini. Sedangkan literasi adalah aktivitas belajar yang dilakukan peserta didik dalam mencapai kompetensi tersebut (PPK, 4c dan HOTS). Pembelajaran ini menurut guru belum menjadi realitas tetapi masih menjadi idealitas. Meskipun demikian, sangat potensial untuk dapat dicapai, tentunya dengan dukungan berbagai pihak.

\section{Kesimpulan}

Bagi guru sejarah, pembelajaran terintegrasi ini menjadi cara untuk mengubah citra pembelajaran sejarah yang selama ini terkesan membosankan, hanya berisi hapalan dan cerita-cerita. Dengan adanya penekanan-penekanan terhadap karakter, literasi, 4c dan HOTS ini baik dalam perencanaan, implementasi maupun penilaian, maka proses pembelajaran gaya lama dapat diperbaiki. Oleh karena itu, semua guru menyambut positif pemberlakuan pembelajaran terintegrasi ini meskipun banyak kendala yang masih di hadapi. Penguatan pendidikan sudah lama diterapkan bahkan sebelum diberlakukannya pembelajaran terintegrasi ini. Sedangkan untuk literasi, masih banyak kendala yang dihadapi karena minat litersi peserta didik masih rendah. Keterampilan $4 \mathrm{c}$ dan HOTS masih dalam proses pencapaian dan upayaupaya yang terus dilakukan oleh guru. Oleh karena itu, untuk dapat mengimplementasi pembelajaran terintegrasi PPK, Literasi, 4c dan HOTS perlu dukungan dari semua pihak, baik pemerintah, sekolah, guru, peserta didik, orang tua dan masyarakat.

\section{Ucapan Terimakasih}

Penelitian ini dilakukan di sekolah-sekolah SMA Negeri di Lombok Timur. Oleh karena itu, peneliti mengucapkan terima kasih kepada semua stake holder yang ada di sekolah atas pemberian izin dan terlaksananya penelitian ini. Terima kasih juga kepada tim peneliti yang telah membantu penelitian ini sehingga dapat diselesaikan tepat waktu.

\section{Daftar Rujukan}

Anderson, L. W. (1981). Assessing affective characteristic in the schools. Boston: Allyn and Bacon.

Anshori, I. (2017). Penguatan Pendidikan Karakter di Madrasah. Halaqa: Islamic Education Journal, 1(2), p. 11-22 
B. Fitri Rahmawati, Muhammad Shulhan Hadi, Zidni

Pembelajaran Sejarah Terintegrasi PPK, Literasi, Keterampilan Abad XXI (4c), dan HOTS

Bernhard, R. (2017). Are Historical Thinking Skills important to history teachers? Some findings from a qualitative interview study in Austria. History Education Research Journal, 14(2), 29-39.

Creswell, J. W. (2015). Penelitian Kualitatif dan Desain Riset Memilih diantara Lima Pendekatan. Yogyakarta: Pustaka Pelajar.

Fernandes, R. (2019). Relevansi Kurikulum 2013 dengan Kebutuhan Peserta Didik di Era Revolusi 4.0. Jurnal Socius: Journal of Sociology Research and Education, 6(2), 70-80.

Haryati, M. (2009). Model dan Teknik Penilaian Pada Tingkat Satuan Pendidikan. Jakarta: Gaung Persada Press.

Hasan, S. H. (2010). Pendidikan Sejarah: Kemana dan Bagaimana? Makalah disajikan pada seminar Asosiasi Guru Sejarah Indonesia (AGSI), Jakarta, 6 Maret 2010.

Hasim, A., Osman, R., Arifin, A., Abdullah, N., \& Noh, N. (2015). Teachers' perception on higher order thinking skills as an innovation and its implementation in history teaching. Australian Journal of Basic and Applied Sciences, 9(32), 215-221.

Jantari, K. H., Bain, B., \& Romadi, R. (2019). Pengembangan Bahan Ajar Handout Materi KH. Ahmad Rifa'i Dalam Pembelajaran Sejarah Perjuangan Kemerdekaan Indonesia di SMA Negeri 1 Bandar. Indonesian Journal of History Education, 7(1), 40-49.

Joebagio, H. (2017). Tantangan Pembelajaran Sejarah di Era Globalisasi. ISTORIA: Jurnal Pendidikan dan Sejarah, 13(1), 55-62.

Kemendikbud. (2017). Konsep dan Pedoman Penguatan Pendidikan Karakter. Jakarta: Kemendikbud.

National Education Association. (2010). Preparing 21st century students for a global society: an educators guide to the "Four Cs". http://www.nea.org/assets/docs/A-Guide-to-FourCs.pdf. Diakses tanggal 17 Agustus 2019.

Novianti, W. K., \& Sugiyono, S. (2018). Factors Causing History Teachers'difficulties In Developing Instructional Teaching in Sleman Regency, Yogyakarta. ISTORIA: Jurnal Pendidikan dan Sejarah, 14(2). 15-25

Pacific Policy Research Center. (2010). 21st Century Skills for Students and Teachers. Honolulu: Kamehameha Schools, Research \& Evaluation Division

Partnership for 21st Century Learning. (2015). P21 Framework Definition. https://www.teacherrambo.com/file.php/1/21st_century_skills.pdf. Diakses tanggal 17 Agustus 2019.

Pi'i. (2016). Mengembangkan Pembelajaran Dan Penilaian Berpikir Tingkat Tinggi Pada Mata Pelajaran Sejarah SMA. Sejarah dan Budaya: Jurnal Sejarah, Budaya, dan Pengajarannya, 10(2), 197-208.

Piawa, C. Y. (2010). Building a test to assess creative and critical thinking simultaneously. Procedia-Social and Behavioral Sciences, 2(2), 551-559.

Prastowo, N. D., Bain, \& Suryadi, A. (2019). Pengaruh Penggunaan Media Komik Sejarah Terhadap Minat Belajar Peserta didik Kelas XI IPS di SMA Negeri 1 Cepogo Tahun Pelajaran 2018/2019 Pokok Bahasan Kerajaan Singhasari. Indonesian Journal of History Education, 7(1), 33-39. 
B. Fitri Rahmawati, Muhammad Shulhan Hadi, Zidni

Pembelajaran Sejarah Terintegrasi PPK, Literasi, Keterampilan Abad XXI (4c), dan HOTS

Rismaya, V. (2018). Pengembanggan Kemampuan Bepikir Kritis-Historis Peserta Didik (Studi Kasus di SMA Semesta Bilingual Boarding School Semarang). Historia Pedagogia, 7(1), 75-82.

Sayono, J. (2013). Pembelajaran Sejarah di Sekolah: dari Pragmatis Ke Idealis. Sejarah dan Budaya: Jurnal Sejarah, Budaya, dan Pengajarannya, 7(1), 9-17.

Sequeira, A. H. 2012. Introduction to Concepts of Teaching and Learning. https://www.researchgate.net/publication/256035169_Introduction_to_Concepts_of_Teaching_ and_Learning/link/5b390b80aca272078500e4e1/download.

Somantrie, H. (2010). "Kompetensi” Sebagai Landasan Konseptual Kebijakan Kurikulum Sekolah di Indonesia. Jurnal Pendidikan dan Kebudayaan, Vol. 16, Nomor 6, hal 684698.

Suyono, S., Harsiati, T., \& Wulandari, I. S. (2017). Implementasi gerakan literasi sekolah pada pembelajaran tematik di sekolah dasar. Sekolah Dasar: Kajian Teori dan Praktik Pendidikan, 26(2), 116-123.

Tok, B. R. (2016). Learning problems in History subject among the Secondary SchoolStudents of Papum-pare district of Arunachal Pradesh. IRA-International Journal of Education \& Multidisciplinary Studies, 5(2), 133-139.

Yusuf, M., Saraswati, U., \& Ahmad, T. A. (2019). Pengembangan Bahan Ajar Perang Lasem dalam Bentuk Booklet Untuk Pembelajaran Sejarah Lokal di SMA Negeri 1 Lasem. Indonesian Journal of History Education, 7(1), 50-58.

Zubaidah, S. (2018). Mengenal 4C: Learning and innovation skills untuk menghadapi era revolusi industri 4.0. In 2nd Science Education National Conference, 13. Universitas Trunojoyo Madura. 